\title{
Middle Miocene Uruguaytheriinae (Mammalia, Astrapotheria) from Peruvian Amazonia and a review of the astrapotheriid fossil record in northern South America
}

\author{
Cyrielle GOILLOT \\ Pierre-Olivier ANTOINE \\ Université Paul-Sabatier, Sciences de la Vie et de la Terre, \\ Observatoire Midi-Pyrénées, Centre National de la Recherche Scientifique, \\ Institut de Recherche pour le Développement, \\ Laboratoire des Mécanismes et Transferts en Géologie, \\ 14 avenue Édouard Belin, F-31400 Toulouse (France) \\ goillot@lmtg.obs-mip.fr \\ poa@Imtg.obs-mip.fr \\ Julia TEJADA \\ Museo de Historia Natural, Universidad Nacional Mayor San Marcos, \\ Departamento de Paleontología de Vertebrados, \\ Avenida Arenales 1256, Lima 11 (Peru) \\ and Institut Français d'Études Andines, \\ Casilla 18-1217, avenida Arequipa 4595, Lima 18 (Peru) \\ juliatejada@gmail.com \\ François PUJOS \\ Instituto Argentino de Nivología, Glaciología y Ciencias Ambientales, \\ CCT-CONICET-Mendoza, avenida Ruiz Leal s/n, \\ Parque General San Martín, 550, Mendoza (Argentina) \\ and Institut Français d'Études Andines, \\ Casilla 18-1217, avenida Arequipa 4595, Lima 18 (Peru) \\ fpujos@yahoo.fr \\ Rodolfo SALAS GISMONDI \\ Museo de Historia Natural, Universidad Nacional Mayor San Marcos, \\ Departamento de Paleontología de Vertebrados, \\ Avenida Arenales 1256, Lima 11 (Peru) \\ rodsalasgis@hotmail.com
}

Goillot C., Antoine P.-O., Tejada J., Pujos F. \& Salas Gismondi R. 2011. - Middle Miocene Uruguaytheriinae (Mammalia, Astrapotheria) from Peruvian Amazonia and a review of the astrapotheriid fossil record in northern South America. Geodiversitas 33 (2): 331-345. DOI: $10.5252 / g 2011 \mathrm{n} 2 \mathrm{a} 8$.

\section{ABSTRACT}

Five mandibular and dental specimens referred to the extinct South American ungulate clade Astrapotheria ar e described. They originate from late middle Miocene deposits of the I pururo Formation in the Río I nuya-Río 
KEY WORDS

Mammalia,

Astrapotheria,

Astrapotheriidae,

Uruguaytheriinae,

Xenastrapotherium,

Granastrapotherium,

Fitzcarrald Arch,

Río Inuya,

Río Mapuya, neotropics.

MOTS CLÉS

Mammalia,

Astrapotheria,

Astrapotheriidae,

Uruguaytheriinae,

Xenastrapotherium,

Granastrapotherium,

Arche de Fitzcarrald,

Río Inuya,

Río Mapuya,

néotropiques.
Mapuya area, Peruvian Amazonia. The first Peruvian astrapothere remains unearthed in a controlled stratigraphical context reveal the co-occurrence of the uruguaytheriine astrapotheriids Xenastrapotherium sp. and Granastrapotherium cf. snorki. Bispecific uruguaytheriine assemblages were so far restricted to the early $\mathrm{M}$ iocene of Venezuela and the late middle $\mathrm{M}$ iocene of Colombia. The Fitzcarrald local fauna, including the ur uguaytheriines described here, recalls unequivocally the Xenastrapotherium kraglievichi Cabrera, 1929-Granastrapotherium snorki assemblage, which characterizes the 13.6-12.76 Ma interval in the Honda Group of La Venta area, Colombia. The spatio-temporal distribution of low-latitude astrapotheriids $\left(<30^{\circ} \mathrm{S}\right)$ is then reviewed, illustrated, and further detailed in both stratigraphical and taxonomic points of view. The group appears in the fossil $r$ ecord during the Oligocene or the earliest M iocene (Uruguaytherium Kraglievich, 1928 and Xenastrapotherium Kraglievich, 1928 in U ruguay and Venezuela, respectively). Uruguaytheriinae are conspicuous elements of middle Miocene mammal assemblages of northern South America (Colombia, Brazil, Bolivia, and now Peru). Astrapotheria probably become extinct during the late Miocene (Huayquerian South American Land Mammal Age), but the youngest specimens are of uncertain taxonomic affinities and/or might be reworked (Astrapotheriidae indet. in Urumaco Formation of Venezuela; ?Astrapotheria in Rio Acre local fauna of Brazil).

\section{RÉSUMÉ}

Les Uruguaytheriinae (Mammalia, Astrapotheria) du Miocène moyen d'Amazonie péruvienne et une revue du registre fossile des Astrapotheriidae dans le nord de l'Amérique du Sud.

Cinq restes mandibulaires et dentaires attribués à des astrapothères, clade éteint de grands ongulés sud-américains, sont décrits. I ls proviennent du Miocène moyen tardif de la Formation Ipururo dans la région du Río Inuya et du Río Mapuya, en Amazonie péruvienne. Les premiers restes d'astrapothères découverts au Pérou dans un contexte stratigraphique contrôlé révèlent la co-existence des Astrapotheriidae Uruguaytheriinae Xenastrapotherium sp. et Granastrapotherium cf. snorki. De tels assemblages bi spécifiques d'Uruguaytheriinae étaient jusqu'alors restreints au Miocène inférieur du Venezuela et au Miocène moyen de Colombie. La faune locale de F itzcarrald, qui inclut les U ruguaytheriinae ici décrits, rappelle sans équiv oque l'association Xenastrapotherium kraglievichi Cabrera, 1929-Granastrapotherium snorki, qui caractérise Pintervalle 13.6-12.76 Ma dans le Groupe Honda de La Venta, en Colombie. La distribution spatiotemporelle des Astrapotheriidae de basse latitude $\left(<30^{\circ} \mathrm{S}\right)$ est ensuite $r$ évisée, illustrée et détaillée à la fois des points de vue stratigraphique et taxinomique. Le groupe apparait dans le registre fossile pendant l'Oligocène ou au Miocène basal (avec Uruguaytherium Kraglievich, 1928 et Xenastrapotherium Kraglievich, 1928, respectivement en Uruguay et au Venezuela). Les Uruguaytheriinae apparaissent comme des éléments habituels des faunes de mammifer es du Miocène moyen d'Amérique du Sud septentrionale (Colombie, B résil, Bolivie et dorénavant Pérou), avant de se raréfier ensuite. Les Astrapotheria ont probablement disparu au cours du Miocène supérieur (étage mammalien Huayquérien), mais les spécimens les plus r écents sont d'affinités incertaines et/ou pourraient être remaniés (Astrapotheriidae indet. dans la F ormation Urumaco au Venezuela; ?Astrapotheria dans la faune locale du Rio Acre au Brésil). 


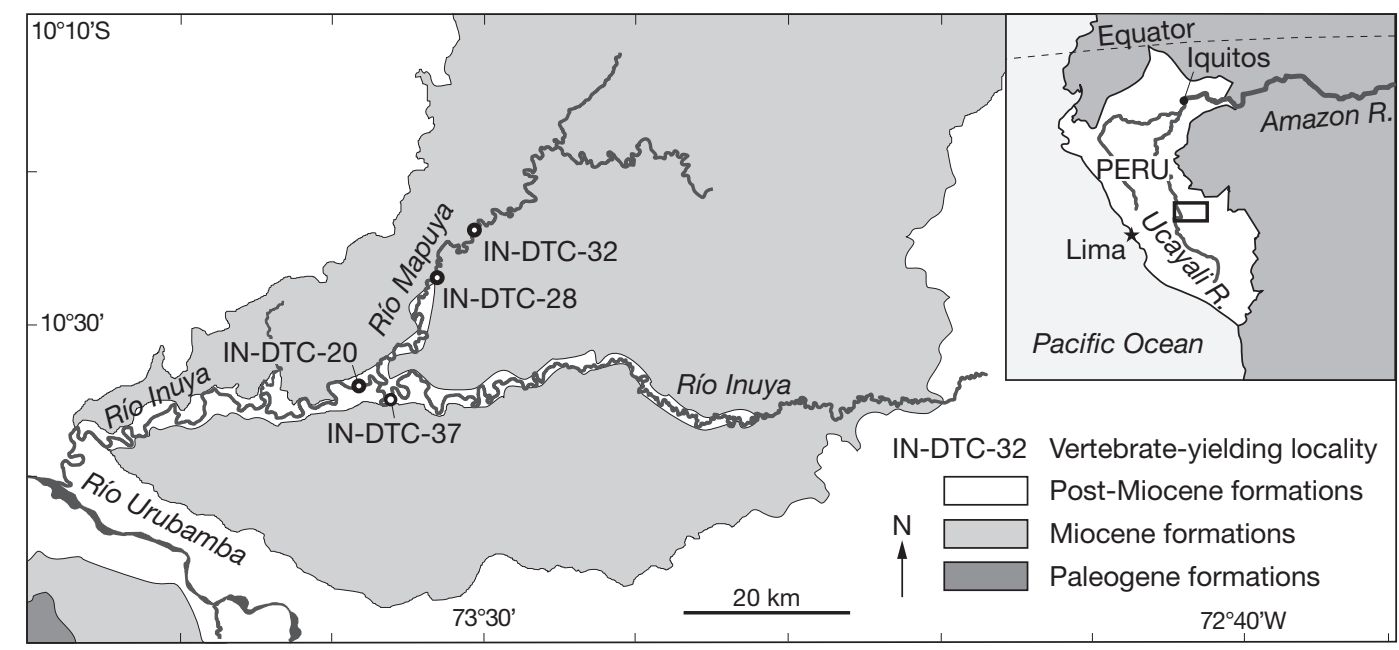

FIG. 1. - Location map of the late middle Miocene astrapotheriid-yielding vertebrate localities in the Río Inuya and Río Mapuya area ("Fitzcarrald local fauna", Ipururo Formation), Ucayali Department, eastern Peru.

\section{INTRODUCTION}

Astrapotheres are an extinct clade of large herbivorous ungulates endemic of South America, grouped into the order Astrapotheria. Their cranial and dental morphology is particularly puzzling, being superficially reminiscent of both rhinoceroses (upper and lower cheek teeth) and elephants (enlarged tusk-like canines and putative proboscis; Ameghino 1894; Scott 1928, 1937; Kramarz \& Bond 2008). The group spans the Paleocene-Miocene period and it ranges from northernmost South America (Venezuela and Colombia; Kraglievich 1928; Cabrera 1929) to West Antarctica (Bond et al. 1990; Hooker 1992). The astrapotheres are usually split into two families, the Palaeocene-Eocene Trigonostylopidae Ameghino, 1901 (Simpson 1967; Cifelli 1993; McKenna \& Bell 1997) and the Focene-Miocene Astrapotheriidae Ameghino, 1887 (Scott 1937; Johnson \& Madden 1997). Based on the phylogenetic analysis poposed by Kramarz \& Bond (2009), the Astrapotheri idae include Astraponotus Ameghino, 1901 (middle Eocene), Maddenia Kramarz \& Bond, 2009 (early Oligocene), and Parastrapotherium Ameghino, 1895 (late Oligocene-early Miocene) as early offshoots (i.e. Astrapotheriidae incertae sedis), as well as the clades Astrapotheriinae and Uruguaytheriinae. The Astra- potheriinae consist of Astrapothericulus Ameghino, 1901 (early Miocene) and Astrapotherium Burmeister, 1870 (early to early middle Mocene). All these genera are restricted to Patagonia and adjacent areas in Argentina and Chile (e.g., Kramarz \& Bond 2008). By contrast, the uruguaytheriine clade traditionally includes post-Eocene astrapotheriids originating from elsewhere in South America: Xenastrapotherium Kraglievich, 1928 (late Oligocene-middle Miocene of northern South America; Johnson \& Madden 1997), Granastrapotherium Johnson \& Madden, 1997 (middle Miocene of Colombia; Johnson \& Madden 1997), and Uruguaytherium Kraglievich, 1928 from Uruguay (Kraglievich 1928; Simpson 1940). In other words, and with the notable exception of Uruguaytherium - the age of which is not well constrained -, Uruguaytheriinae are restricted to Northern South America, ranging from Colombia and Venezuela to the North to southern Bolivia to the South (Kraglievich 1928; Cabrera 1929; Hoffstetter 1977; Frailey 1987; Johnson \& Madden 1997; Croft 2007).

In August 2005, a French-Peruvian team explored the Ríos Inuya and Mapuya (Fig. 1), focusing on geological data (Espurt et al. 2006, 2007, 2010) and palaeontological evidence (Antoine et al. 2007; Salas-Gismondi et al. 2007). Among hundreds of 
vertebrate remains unearthed in the Inuya-Mapuya area in 2005, five mandibular and dental specimens can be referred to Astrapotheria. With the exception of a lower molar and a left edentulous maxilla collected floating on a bank along the Río Inuya - "Locality VF56, Playa Mapuya” according to Willard (1966) and subsequently referred to the ur uguaytheriine astrapotheriid cf. Granastrapotherium (Johnson \& Madden 1997), this order was unknown in Peru to date. This work is aimed to describe and identify the first Peruvian astrapothere assemblage unearthed in a controlled stratigraphical context.

\section{GEOGRAPHICAL}

\section{AND GEOLOGICAL SETTING}

The Fitzcarrald Arch shows widespread dissected relieves of Miocene sediments coeval to the more northern Pebas deposits (Espurt et al. 2007, 2010). The Inuya localities are located in a slightly deformed part of the Fitzcarrald Arch (Fig. 1; Regard et al. 2009). They correspond to middle Miocene outcrops of the Amazon foreland strata, with tidal facies attesting the presence of giant estuaries alimented by Andean rivers (Espurt et al. 2007, 2010).

Vertebrate remains accumulate mainly in Mocene conglomerates from the Ipururo Formation, interpreted as storm deposits channelized in nearshore environment (Espurt et al. 2007, 2010). These conglomerates are topped by tidal deposits yielding some scattered vertebrates and fossil wood. Pliocene conglomerates and sandstones of the Juanjui Formation, with fossil wood but no vertebrate, unconformably overlay these tidal Miocene sandy clays. Pleistocene units correspond to terrace deposits of the Ucayali Formation, placed $50 \mathrm{~m}$ abo ve the Río Mapuya (Regard et al. 2009; Espurt et al. 2010).

\section{MATERIAL AND METHODS}

The described material is stored in the Paleontology Department of the MUSM.

Comparison with other representatives of Astrapotheria was performed thanks to the collections stored in the MACN, the MLP, the MUSM, the
UCMP, the Field Museum of Natural History (Chicago), the American Museum of Natural History (New York), the Yale Peabody Museum (New Haven), the Museo Nacional de Historia Natural (La Paz), the Universidad Nacional de Colombia (Bogotá), the Museo Geológico Nacional del Instituto Colombiano de Geología y Minería (Bogotá), and the Muséum national d'Histoire naturelle (Paris).

\section{ABBREVIATIONS}

Upper case letters are used for upper dentition (I, $\mathrm{C}$, $\mathrm{P}$, and $\mathrm{M}$ ) and lower case letters for lower dentition (i, c, p, and $\mathrm{m}$ ).

\section{Institutions}

MACN Museo Argentino de Ciencias $\mathrm{N}$ aturales, Buenos Aires, Argentina;

MLP Museo de Ciencias Naturales, La Plata, Argentina;

MUSM Museo de Historia Natural de la Universidad Nacional Mayor de San Marcos, Lima, Peru;

UCMP University of California Museum of Paleontology, Berkeley, USA.

\section{Other abbreviations}

APD anteroposterior diameter;

$\mathrm{H}$ height;

LLL labio-lingual length;

max maximal;

MDL mesio-distal length;

SALMA south american land mammal age.

\section{SYSTEMATICS}

The systematic arrangement her eunder follows that proposed by McKenna \& Bell (1997) and Johnson \& Madden (1997), refined by Kramarz \& Bond (2009).

Two other fragmentary specimens unearthed in the field in 2005 were doubtfully referable to Astrapotheria (MUSM F-2005-58: partial edentulous mandible symphysis from IN-DTC-32, mentioned by Antoine et al. (2007); MUSM F-2005-005: small fragment of a canine, from IN-007). We chose not to include them in the follo wing description, as they would not provide further morphological or taxonomic information on the current astrapotheriid assemblage. 
Class MAMMALIA Linnaeus, 1758

Order ASTRAPOTHERIA Lydekker, 1894

Family AsTRAPOTHERIIDAE Ameghino, 1887

Subfamily URUgUaYTHERIINAE Kraglievich, 1928

Genus Xenastrapotherium Kraglievich, 1928

TYPE SPECIES. - Astrapotherium christi Stehlin, 1928 from the ?late Oligocene-early Miocene of Venezuela, by original designation (Kraglievich 1928).

OTHER REFERRED SPECIES. - Xenastrapotherium kraglievichi Cabrera, 1929, middle Miocene of Colombia; $X$. amazonense Paula Couto, 1976, middle M iocene of Brazil; X. aequatorialis Johnson \& Madden, 1997, early Miocene of Ecuador; X. chaparralensis Johnson \& Madden, 1997, early Miocene of Colombia.

\section{Xenastrapotherium sp.}

(Fig. 2)

?Xenastrapotherium sp. - Antoine et al. 2007: 21.

Granastrapotherium snorki (partim) - Antoine et al. 2007: 21.

Xenastrapotherium sp. - Negri et al. 2010: 247.

MATERial eXAMined. - Edentulous symphysis with canine alveoli (MUSM 1468) and left i1 (MUSM 1466), IN-DTC 20 locality; left P3 without ectoloph (MUSM 1467), IN-DTC 37 locality.

LOCALiTy AND DisTRibution. - Río Inuya, c. $2 \mathrm{~km}$ downstream the confluence with Río Mapuya (IN-DTC 20) and c. $500 \mathrm{~m}$ upstream the confluence with Río Mapuya (IN-DTC 37), Atalaya Department, Ucayali, Peru (Fig. 1).

FORMATION AND AGE. - Ipururo Formation, c. $500 \mathrm{~m}$ above the base of the formation, late middle $\mathrm{M}$ iocene, c. $13 \mathrm{Ma}$ (Antoine et al. 2007; Espurt et al. 2010).

\section{DESCRIPTION}

MUSM 1468 is a much damaged fragment of an edentulous mandibular symphysis (Fig. 2A-F). In dorsal view, the symphysis is sagittally elongate (preserved APD $=117 \mathrm{~mm}$ ), with a shallov sagittal gutter between canine alveoli; only the lingual pait of them is preserved, on each side of the symphysis; the preserved part of the concerned alv eolus has a circular transverse section; the canines were hypsodont to hypselodont; they w ere converging frontward in the posterior half of the symphysis, parallel, then diverging in the anterior half; thee is neither obligate alveoli for front teeth (incisors) nor for cheek teeth in the preserved part; the posterior border of the symphysis is r egularly concave; the intermandibular space was very wide and reached c. $50 \mathrm{~mm}$. In rostral view, the ventral border of the symphysis is slightly convex; the dorsal border, corresponding to the shallow sagittal gutter described before, is regularly concave between the canine alveoli; three shallow circular pits are observed on the rostral tip of the symphysis ; two ar e located on the left side while a single one is pr eserved on the right side; they ar e not perfectly symmetrical with respect to the median axis, and as such, cast a doubt on their meaning; nevertheless, the most probable hypothesis is that they could $\mathrm{r}$ epresent vestigial incisor alveoli. In lateral view, both ventral and dorsal borders are parallel and sub-horizontal; canine alveoli are also horizontal in their central part and slightly oriented up ward in their rostral and caudal parts. In ventral view, four mental foramina open forming a small irr egular semicircle in the rostral part of the symphysis; two larger foramina, more remote than the latter, are visible close to the caudal border of the symphysis; this caudal border is large and regularly concave.

MUSM 1467 is a worn and broken biradiculate tooth (max preserved MDL = $21.6 \mathrm{~mm}$; max preserved $\mathrm{LLL}=22.1 \mathrm{~mm}$; est $\mathrm{LLL} \approx 25 \mathrm{~mm}$ ). The labial and lingual roots are totally fused distally and separate by a deep longitudinal groove on the mesiolingual side (Fig. 2I, J). Except where worn or broken, the crown is surrounded by finely wrinkled enamel. The ectoloph is badly broken and enamel is completely lacking on it. I n occlusal view, the crown is triangular, wider distally than mesially, and with a slightly convex lingual edge (Fig. 2G, $\mathrm{H}$ ); the single lingual cusp (?pr otocone) is conical and anteriorly connected to the ectoloph b y a thin and low crest interpreted as a protoloph; a short, low and oblique cingulum is visible on the mesiolingual side of the tooth; the preserved part of the ectoloph is slightly higher than the pr otocone; distally, the ectoloph and the protocone are 
connected by a thick and worn cest, thus forming a metaloph at late stages of wear; the mesiolingual pocket forms a circular pit; the weak distal cingulum is low and smooth, thicker labially, and defining a low distal pocket.

MUSM 1466 is a worn incisiform tooth, with a low crown and a long and single root $(c .40 \mathrm{~mm}$ long; Fig. 2K-M). Except where worn, the crown is entirely surrounded by finely wrinkled enamel. In occlusal view, the crown is sub-oval $(\mathrm{MDL}=$ $17.4 \mathrm{~mm}$; LLL $=12.4 \mathrm{~mm}$ ), with two convex and elongate opposite sides (i.e. lingual/labial), slightly converging on the right side; thee is a low horizontal cingulid, located just abo ve the neck on both sides, but no vertical groove. The root is flattened transversely and elongate sagittally.

\section{COMPARISON}

MUSM 1468 was first mentioned by Antoine et al. (2007) as documenting Granastrapotherium snorki, but further observation revealed the putative presence of three incisor alveoli, which precludes its referral to G. snorki (devoid of incisors; Johnson \& Madden 1997). At the same time, similar alv eoli occur in early ontogenetic stages of $X$. kraglievichi from La Venta (UCMP 45069). Orientation of the canines (nearly horizontal) is similar to that observed in $X$. kraglievichi (UCMP 45069), and at a lesser degree to G. snorki (UCMP 40017), in which they ae perfectly horizontal. On the other hand, their orientation is pretty distinct from what is observed in the holotypes of Parastrapotherium martiale Ameghino, 1901 (MACN A52-604) and of Astrapotherium giganteum Ameghino, 1898 (MACN A3274-3278), as well as in the mandible MACN 3207 (A. magnum Burmeister, 1879), i.e. upraised.

The triangular occlusal outline and distal widening of MUSM 1467 do not match the P4s referred to G. snorki (rounded) and to X. kraglievichi (quadrangular), while such featur es are observable on the P3 UCMP 38847 fr om La Venta, belonging to the hypodigm of $X$. kraglievichi, as illustrated by Johnson \& Madden (1997: figs 22.1; 22.3). Besides, the estimated dimensions of MUSM 1467 (c. $22 \times 25 \mathrm{~mm}$ ) ae similar to those of UCMP 38847 $(\mathrm{MDL}=20.5 \mathrm{~mm} ; \mathrm{LLL}=23.4 \mathrm{~mm}$; ohnson \& Madden 1997: table 22.1). Granastrapotherium does not retain $\mathrm{P} 3$ and $\mathrm{P} 4$ is much larger (range $=26.7$ $38.4 \mathrm{~mm}$; mean $=33.2 \mathrm{~mm}$; Johnson \& Madden 1997: table 22.4).

The presence of enamel all around the crown of MUSM 1466 impedes referring it to a to xodont notoungulate, the only associated astrapothere-sized taxon. When compared to astrapothere teeth, this unicuspid, single-rooted, and brachydont tooth can be identified as a lower incisor. The crown is low, which points either to an il or i3, rather than to an i2 (high-crowned). Furthermore, its bilateral symmetry implies it was located axially on the symphysis. As a consequence, it is tentatiely interpreted as an i1, which tends to be confrmed by its strong sagittal development and by the strong wear of the crown. Moreover, Astrapotheriidae generally display deep median longitudinal gr ooves on both labial and lingual sides of the incisors (i1-i3), and their absence is only observed in i1s of a for astrapotheriid taxa. MUSM 1466 differs from those referred to Astrapotherium (Santacrucian SALMA, Argentina: MACN 3207; Colhuehuapian SALMA, Argentina: A52-513 and A52-525; Kramarz \& Bond 2010), Astrapothericulus Ameghino, 1901 (Santacrucian, Argentina: MACN A52-405; Kramarz 2009) and Parastrapotherium (Deseadan SALMA, Argentina: MACN A52-506), but is similar to ils of the early astrapotheriid Astraponotus (Mustersan/ Deseadan SALMA, Argentina; MLP 52-XI-4-151160). Granastrapotherium is devoid of any incisor (Johnson \& Madden 1997). The incisors referred to Xenastrapotherium from the Honda Group, Colombia, have shallow median grooves restricted to the distal half of the cr own, which disappear before late stages of $\mathrm{w}$ ear (direct observation by C.G., UCMP, Bogotá). Given the stratigraphical context of IN-DTC 20, MUSM 1466 cannot be referred to Astraponotus; its morphology would be consistent with that of Xenastrapotherium.

Following Johnson \& Madden (1997), two species are referred to Xenastrapotherium in the middle Miocene of northern South America, but X. amazonense Paula Couto, 1976 (Brazil) might be a junior synonym of X. kraglievichi Cabrera, 1929 (Colombia). However, given the present sample and pending a taxonomic revision of the genus, we refer to the corresponding remains as Xenastrapotherium sp. 

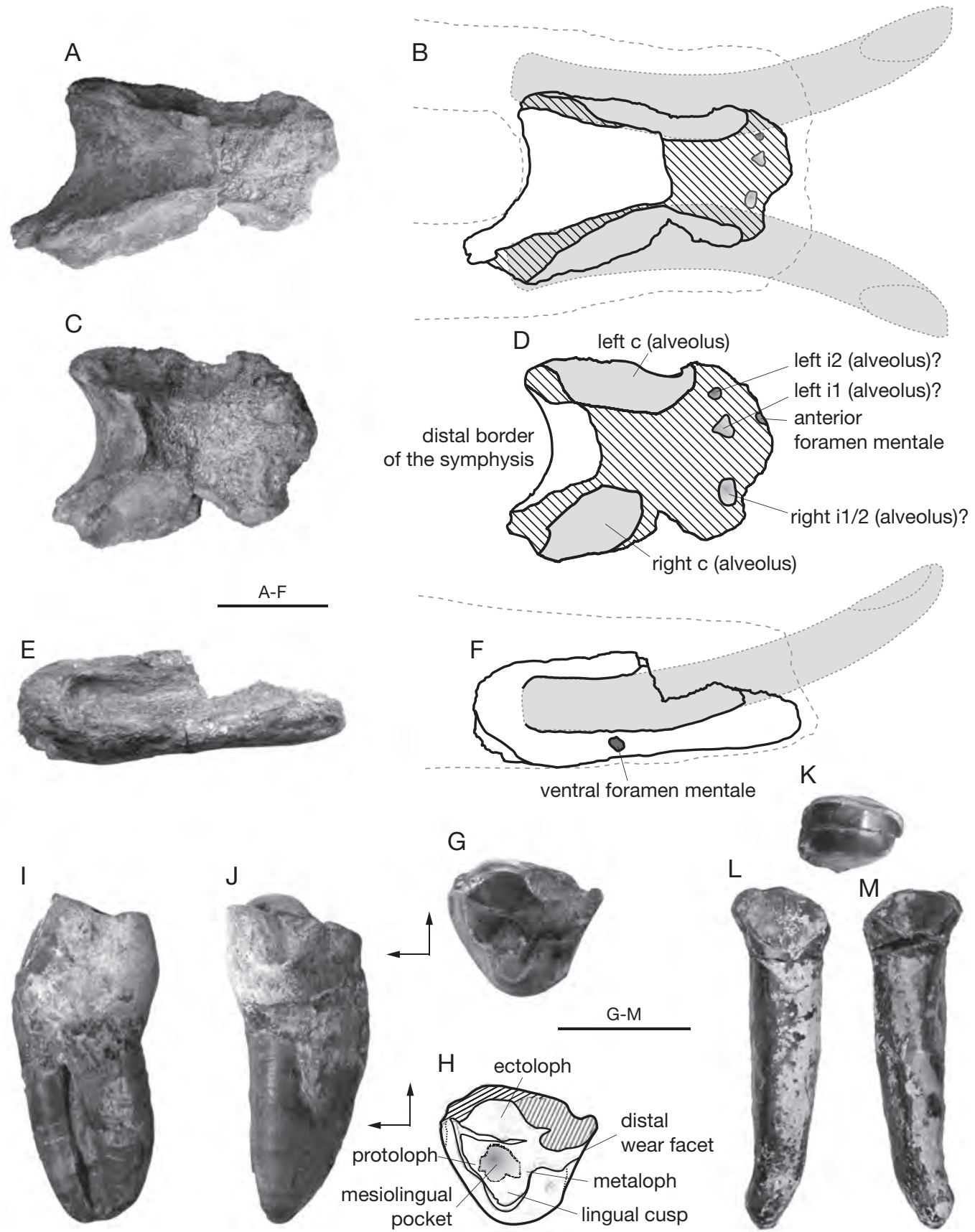

FIG. 2. - Xenastrapotherium sp. from the late middle Miocene Fitzcarrald local fauna, Peruvian Amazonia: A-F, edentulous symphysis with canine alveoli (MUSM 1468), IN-DTC 20 locality; A, dorsal view; B, interpretative reconstruction with canines, same view; C, rostro-dorsal view; D, interpretative reconstruction with alveoli of anterior teeth, same view; $\mathbf{E}$, right lateral view; $\mathbf{F}$, interpretative reconstruction with canines, same view; G-J, left P3 without ectoloph (MUSM 1467), IN-DTC 37 locality; G, occlusal view; H, interpretative sketch of the occlusal view, with main observed features; I, mesiolingual view; J, distal view; K-M, left i1 (MUSM 1466), IN-DTC 20 locality; K, occlusal view; L, labial view; M, lingual view. Leftward and upward arrows show mesial and labial sides, respectively. Scale bars: A-F, 50 mm; G-M, 20 mm. 


\section{Genus Granastrapotherium \\ Johnson \& Madden, 1997}

TYPE AND ONLY SPECIES. - Granastrapotherium snorki Johnson \& Madden, 1997 from the middle Miocene of Colombia, by original designation.

\section{Granastrapotherium cf. snorki}

(Fig. 3)

Granastrapotherium snorki (partim) - Antoine et al. 2007: 21.

Granastrapotherium snorki - Negri et al. 2010: 247.

MATERIAL EXAMINED. - Left broken M2, without ectoloph (MUSM 994), IN-DTC 28 locality (float); fragmentary ectometaloph of a left M3 (MUSM 1477), IN-DTC-32 locality.

LOCALITY AND DisTRIBUTION. - Río Mapuya, 14 km upstream the confluence with Río Inuya (IN-DTC 28) and $7 \mathrm{~km}$ upstream the latter locality (IN-DT C-32), Atalaya Department, Ucayali, Peru, and Río Inuya.

FORMATION AND AGE. - Ipururo Formation, late middle Miocene, c. $13 \mathrm{Ma}$ (Antoine et al. 2007; Espurt et al. 2010).

\section{DESCRIPTION}

MUSM 994 is a worn and broken tooth, lacking its labial part and its roots. The crown as a whole, except where worn or broken, is surrounded by finely wrinkled enamel (Fig. 3A). The complete crown is elongate sagittally. In occlusal view, the labial third of the crown is broken; the protoloph is nearly parallel to the preserved part of the ectoloph; the anterior and posterior sides make an angle of c. $45^{\circ}$ converging lingually; the protocone and the labial part of the protoloph are very large at this advanced wear stage; the protocone is constricted anteriorly by a large valley and it shows a lingual groove (Fig. 3B); a bulge is obseved on the lingual side of the ectoloph; a large median $\mathrm{v}$ alley opens lingually; a thick hypocone joins the ectoloph, thus forming a metaloph, separate from the ectoloph by a sharp groove; no lingual cingulum can be obseved; thickness of the enamel varies from $0.5 \mathrm{~mm}$ on the lingual side of the ectoloph to $1.7 \mathrm{~mm}$ on the anterior side of the protocone. The tooth is $60 \mathrm{~mm}$ long and its estimated dimensions once $r$ econstructed (Fig. 3C) are $70 \mathrm{~mm}$ (ectoloph MDL), $60 \mathrm{~mm}$ (anterior LLL), and $38 \mathrm{~mm}$ (posterior LLL).

MUSM 1477 is the posterior pat of the ectoloph of an M3, with a sharp and oblique occlusal edge. The enamel is finely striated vertically. The preserved height reaches $73 \mathrm{~mm}$.

\section{COMPARISON}

MUSM 994 is "П-shaped" (two transverse lophs and an ectoloph) and brachydont, and it displays a mesial valley (anterior constriction of the protocone), which allows us to interpret it as an upper molar of an astrapothere, rather than a to xodont tooth (Fig. 3). The protocone is large and conical and the lingual valley is deep; despite the adranced stage of wear, its sagittal elongation tends to indicate MUSM 994 is not an M1, while the pr esence of a conspicuous metaloph-hypocone crest impedes identifying it as a M3 either. On the other hand, the general shape of the tooth fts perfectly M2s of uruguaytheriine astrapotheres (Johnson \& Madden 1997). There is no lingual cingulum, contrarily to what is observed in all astrapotheriids, including Xenastrapotherium (Johnson \& Madden 1997; Kramarz \& Bond 2009). Together with the large size of the tooth $(c .70 \times 60 \mathrm{~mm}$, i.e. ex ceeding by $10 \%$ the largest M2 referred to $X$. kraglievichi, but coinciding with the mean value for G. snorki; Johnson \& Madden 1997: tables 22.1; 22.4), the absence of lingual cingulum strongly supports the assignation of MUSM 994 to Granastrapotherium. Accordingly, due to its very large dimensions (c. 30\% larger than M3s of X. kraglievichi; Johnson \& Madden 1997; pers. obs. CG 2008), the fragmentar $y$ ectometaloph MUSM 1477 is likely to document the same large-sized taxon, tentatively referred to as Granastrapotherium cf. snorki.

\section{DISCUSSION}

\section{AgE OF THE FitZCARRALD LOCAL FAUNA,} EASTERN PERU

The specimens described in the present work substantiate the uruguaytheriine astrapotheriid record in Amazonian Peru, primarily based on fbat speci- 
mens from the Río Inuya/Mapuya area mentioned by Willard (1966) and subsequently referred to "cf. Granastrapotherium” by Johnson \& Madden (1997). The new remains document two uruguaytheriine taxa: Xenastrapotherium sp. and Granastrapotherium cf. snorki. In northern South America, bispecific astrapotheriid assemblages were so far restricted to the early Miocene of Venezuela (Castillo Formation; Sánchez-Villagra et al. 2004), and the late middle Miocene of Colombia (Honda Group; Johnson \& Madden 1997).

Such co-occurrence recalls unequivocally the Xenastrapotherium kraglievichi-Granastrapotherium snorki assemblage, which characterizes the late middle Miocene "Miocochilius Assemblage Zone" of La Venta, Colombia (Johnson \& Madden 1997; Madden et al. 1997). By the way, the Fitzcarrald local fauna also includes other biostratigraphical markers of the Laventan SALMA (13.5-11.8 $\mathrm{Ma})$, such as the small interatheriid notoungulate Miocochilius anomopodus Stirton, 1953, the large toxodontid notoungulate Pericotoxodon platignathus Madden, 1997, and the dinomyid rodents "'Olenopsis' sp., large" sensu Walton 1997 and "Scleromys" schurmanni sensu Walton 1997 (Antoine et al. 2007). This assemblage as a whole fur ther points to the 13.6-12.76 Ma interval in the Honda Group of Colombia (C5ABn-C5Ar.2r chrons; Madden et al. 1997: fig. 29.6; Gradstein et al. 2005: 68, table 5.2). To a lesser extent, the Fitzcarrald local fauna resembles the Quebrada Honda assemblage of southern Bolivia, which notably yields another species of Miocochilius, M. federicoi Croft, 2007, and a large uruguaytheriine astrapotheriid (Antoine et al. 2007; Croft 2007).

\section{THE ASTRAPOTHERIID FOSSIL RECORD}

\section{IN NORTHERN SOUTH AMERICA}

The spatio-temporal distribution of unguaytheriine astrapotheres is illustrated in the F igure 4 and further detailed in the section below. In high- and middle-latitudes ( $>30^{\circ} \mathrm{S}$; mostly fr om Argentina and Chile), the last astrapotheriids ar e reported during the "Friasian" stage (e.g., Pascual \& Odreman Rivas 1971). This informal stage represents a short interval intercalated between the late early Miocene Santacrucian SALMA and the early middle Mocene
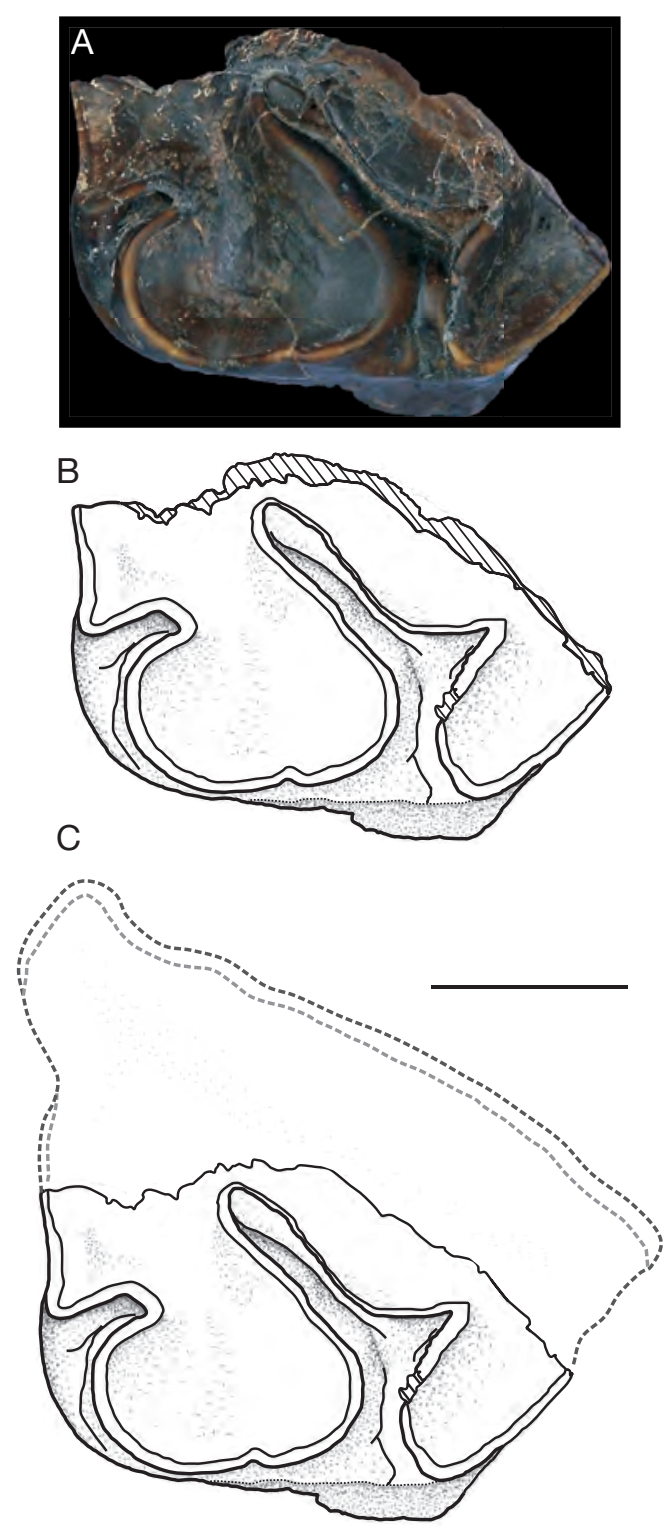

FIG. 3. - Granastrapotherium cf. snorki from the late middle Miocene Fitzcarrald local fauna, Peruvian Amazonia. Left broken M2 without ectoloph (MUSM 994), IN-DTC 28 locality (float): A, occlusal view; $\mathbf{B}$, interpretative sketch of the occlusal view; C, tentative reconstruction of the whole tooth. Scale bar: $20 \mathrm{~mm}$.

Colloncuran SALMA (Flynn et al. 2002, 2008; Croft 2007; Forasiepi et al. 2009; Kramarz \& Bond 2009). Therefore, uruguaytheriines as conspicuous 
elements of the mammalian faunas ar e the last well-documented representatives of Astrapotheria, throughout the late middle $\mathrm{M}$ iocene (Laventan SALMA; Johnson \& Madden 1997). They might persist until middle late Miocene times (Huayquerian SALMA) in Venezuela and Amazonian Brazil, with fragmentary remains only identified at family level and likely to be $r$ eworked or misidentified (Frailey 1986; Linares 2004; Carlos Jaramillo pers. com. 2008).

Xenastrapotherium is widely distributed, both stratigraphically (ranging at least fr om the early Miocene to the late middle $\mathrm{M}$ iocene) and geographically (Venezuela, Colombia, Ecuador, Brazil, and Peru; Fig. 4). Xenastrapotherium chaparralensis, from the Chaparral local fauna of Colombia Tuné Formation, Tolima Department), was formerly considered as the earliest unguaytheriine, dating back from the Deseadan (Stirton 1953). The associated mammalian assemblage suggests this fauna is rather Colhuehuapian or early Santacrucian in age (early Miocene; Johnson \& Madden 1997: 365).

A single mandible described b y Stehlin (1928) documents $X$. christi. It originates from the "Cucharo Formation”, near Zaraza, northeastern Guárico State, Venezuela (Stehlin 1928; Simpson 1940). This formation was later synonymiz ed with the Chaguaramas Formation, which spans the late Oligocene-early Miocene interval (Isea 1987). As such, $X$. christi might be the earliest unguaytheriine with Uruguaytherium, for which an Oligocene age cannot be discarded either (see hereafter; Simpson 1940).

Xenastrapotherium aequatorialis is also known only by a partial right mandible with $\mathrm{m} 1-\mathrm{m} 2$, "reported to have been collected along the banks of the Río Burgay [...] $1 \mathrm{~km}$ south of Bblián, Province of Cañar, Ecuador" (Johnson \& Madden 1997: 362). Several K-Ar datings on andesitic lavas at the top of the Biblián Formation, which crops out in that area, constrain an early $\mathrm{M}$ iocene age for this mandible $(>19.7 \pm 0.5 \mathrm{Ma}$; for review see Lavenu et al. 1995).

By contrast, the mandibular and dental morphology of $X$. kraglievichi is well documented, with about three dozens referred specimens from various localities of the Villavieja Formation, La Venta area,
Colombia (Johnson \& Madden 1997). Following the same authors and Madden et al. (1997: 508, fig. 29.5), a right M3 originating from the uppermost vertebrate locality of the underlying La Victoria Formation, in the same ar ea, is also referable to $X$. kraglievichi. The corresponding stratigraphical interval is magnetostratigraphically constrained, and ranging from 13.183 up to $12.73 \mathrm{Ma}$ (Madden et al. 1997; Gradstein et al. 2005).

Xenastrapotherium amazonense is known by a maxillary fragment with M3 fr om Pedra Pintada locality (Paula Couto 1976) and several teeth from Cachoeira locality (= Torre Da Lua; Rancy 1981) found on banks of the Alto Río yruá, in Amazonian Brazil (Paula Couto 1976, 1982; Johnson \& Madden 1997; Negri et al. 2010). Several fragmentary teeth originating from surrounding localities were either referred to as "?Synastrapotherium amazonense" by Paula Couto (1976), "Astrapotheriinae indet." (sensu Simpson 1945, i.e. corresponding to Astrapotheriidae sensu McKenna \& Bell 1997) by Rancy (1981), or Astrapotheriidae incertae sedis by Paula Couto (1982). All these remains originate from middle or early late Miocene deposits of the Rio J uruá-Río Breu confluence area, at the Peruvian border (Paula Couto 1976, 1982; Negri et al. 2010).

At last, the present work extends the geographical range to Amazonian Peru, with Xenastrapotherium sp. reported here from the Fitzcarrald local fauna (late middle Miocene, eastern Peru), in deposits roughly coeval to the Alto Juruá fossiliferous levels (Fig. 4; Negri et al. 2010).

Granastrapotherium s.s. was so far estricted to the middle Miocene Honda Group of Colombia, with c. 30 cranio-dental and postcranial emains referred to $G$. snorki, ranging from the base of La Victoria Formation (near Coima, Tolima Department) up to the Polonia Red Beds of the upper Villavieja Formation in La Venta area, $50 \mathrm{~km}$ more to the South (Johnson \& Madden 1997; Madden et al. 1997). From a chronostratigraphical point of view, the corresponding interval ranges from $13.734 \mathrm{Ma}$ up to $12.82 \mathrm{Ma}$ (Madden et al. 1997; Gradstein et al. 2005). Granastrapotherium is the only ur uguaytheriine for which appendicular skeleton is somewhat available (Johnson \& Madden 1997). In addition, two craniodental specimens collected 


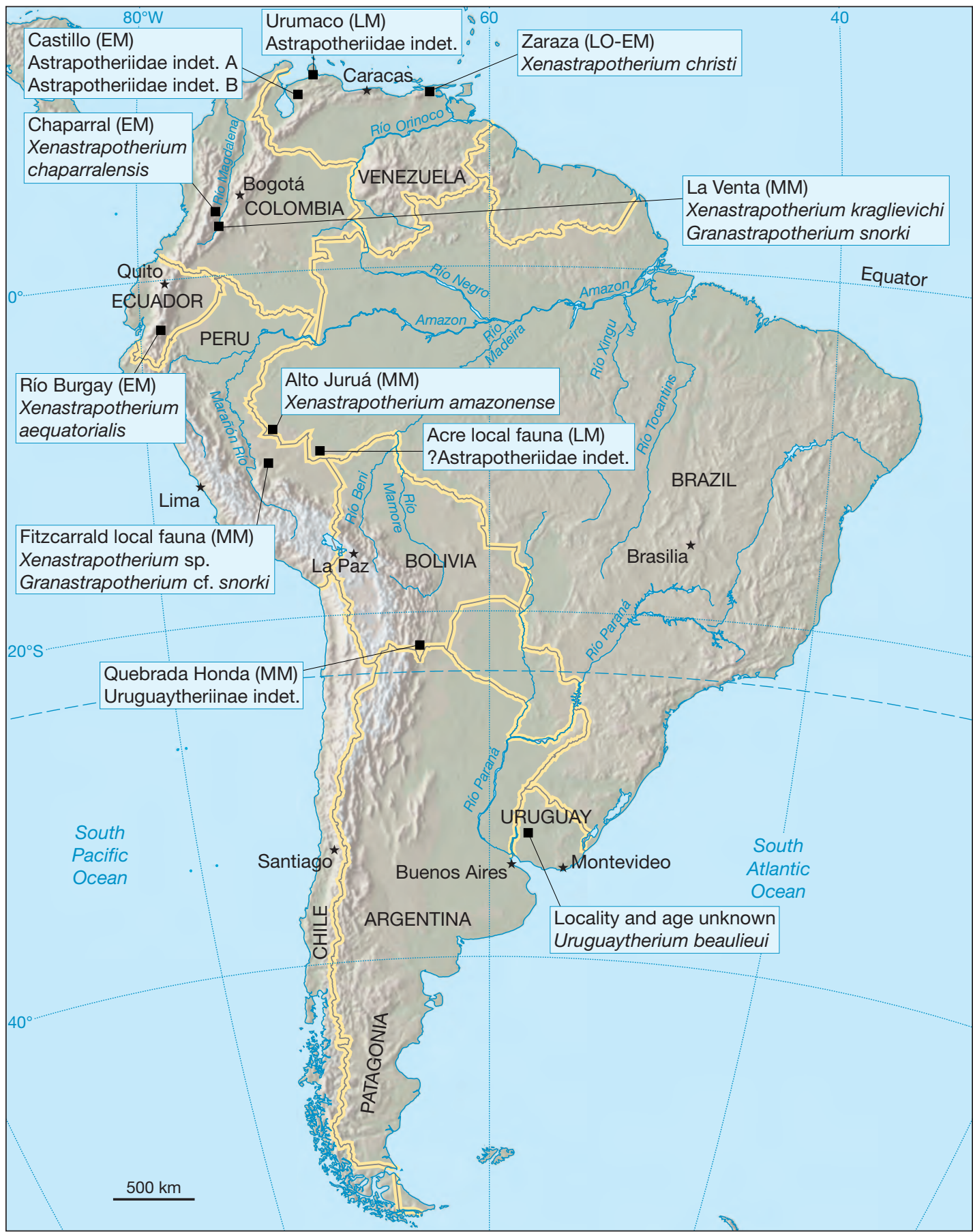

FIG. 4. - Location map and fossil record of northern South American Astrapotheriidae Ameghino, 1887, based on data from Kraglievich (1928), Stehlin (1928), Scott (1937), Simpson (1940), Paula Couto (1976, 1982), Rancy (1981), Frailey (1986, 1987), Isea (1987), Johnson \& Madden (1997), Flynn et al. (2002, 2008), Sánchez-Villagra et al. (2004), Weston et al. (2004), Antoine et al. (2007), Croft (2007), and Negri et al. (2010). Abbreviations: LO, late Oligocene; EM, early Miocene; MM, middle Miocene; LM, late Miocene. 
by Willard (1966) in the Río Inuya/Mapuya area of eastern Peru - without stratigraphical contr ol neither opportunity for comparing the pr esent specimens - document a close ally, referred to as cf. Granastrapotherium by Johnson \& Madden (1997). The remains described in the present work originate unambiguously from the same levels and might document the same tax on (Granastrapotherium cf. snorki).

Uruguaytherium beaulieui Kraglievich, 1928 is the type and only species ieferred to Uruguaytherium. It is based on a single specimen, a left mandible with $\mathrm{m} 2-\mathrm{m} 3$ originating from an unknown locality of western Uruguay (“Río Negro Dept."), assumed to be either Oligocene or Miocene in age (Kraglievich 1928; McKenna \& Bell 1997).

Other astrapotheriid remains with uncertain taxonomic affinities were reported from several Miocene localities of nor thern South America in the last decades (Fig. 4): a bispecific assemblage based on five postcranials from the early Miocene Castillo Formation is described at Cerro La Cruz, western Venezuela ("Astrapotheriidae indet. A" and "Astrapotheriidae indet. B"; Sánchez-Villagra et al. 2004; Weston et al. 2004).

A large uruguaytheriine occurs in the middle Miocene of Quebrada Honda, South Bolivia: Hoffstetter (1977) first referred several isolated teeth to the "Uruguaytherium-Xenastrapotherium group". Then, a badly preserved neurocranium, larger than those of Astrapotherium, was described as belonging to "?Xenastrapotherium" by Frailey (1987). Given the large dimensions of the coresponding remains, notably its bizygomatic width, referral to the latter genus was discarded for the benefit of "Uruguaytheriinae, gen. et sp. incertae sedis" (Johnson \& Madden 1997: 377). The age of the concerned deposits is extrapolated at c. 12.7-13.0 Ma (K/Ar and magnetostratigraphy; MacFadden et al. 1990), which coincides with the middle part of the late middle Miocene Laventan SALMA (Croft 2007).

To our knowledge, only two late Miocene astrapotheriid mentions are reported in the literature. "Astrapotheriidae indet. A" and "Astrapotheriidae indet. B" - distinct from the unidentified astrapotheriids found in association in the early Mocene of western Venezuela (Fig. 4), as reported by Weston et al. (2004) and discussed abo ve - occur in the middle and the upper member of the $U$ rumaco Formation of Northern Venezuela, respectively (Linares 2004). The nature and number of the corresponding remains (grouped as "Astrapotheriidae indet." in Figure 4) are not detailed, except that they are badly preserved and/or fragmentary, which might indicate they are reworked from underlying formations of the same area, such as the Laventan Socorro Formation, as it often occurs (Linar es 2004; Carlos Jaramillo pers. com. 2008). Owing to mammalian and foraminiferan biochronology, the concerned deposits are assumed to be middle late Miocene in age (Chasicoan-Huayquerian SALMAs; Linares 2004).

At last, an upper canine originating fom the late Miocene Río Acre local fauna of Amazonian Brazil (Huayquerian SALMA; Cozzuol 2006), originally identified as "Xenastrapotherium amazonense" by Frailey (1986, fig. 26D), was subsequently "referred only questionably to Astrapotheria” (Johnson \& Madden 1997: 366).

To sum up, the late Miocene astrapotheriid record is far from being well constrained, and a late middle Miocene - Laventan - age for the Last Appearance Datum of Astrapotheria cannot be discarded to date.

\section{Acknowledgements}

The authors are grateful to Andréa Maciente and Alceu Rancy (Universidade Federal do Acre, Rio Branco, Brazil), to Christine Argot, Claire Sagne, and Pascal Tassy (Muséum national d'Histoire naturelle, Paris), and to John J. Flynn (American Museum of Natural History, New York) for having granted access to the collections they are in charge of. Curators of the Field Museum of Natural History (Chicago), the University of California Museum of Paleontology (Berkeley), the Yale Peabody Museum (New Haven), the Museo Nacional de Historia Natural (La Paz), the Museo Argentino de Ciencias Naturales (Buenos Aires), the Museo de Ciencias Naturales (La Plata), the Universidad Nacional de Colombia (Bogotá), and the M useo Geológico Nacional del Instituto Colombiano de Geología y Minería (Bogotá) are warmly thanked. 
This research project was led thanks to the IRDPerupetro S.A. research agreement, and supported by IRD (UR 154) and French INSU-CNRS programmes DyETI (Dynamique et Évolution de la Terre Interne) and ECLIPSE II (Érolution néogène du bassin amazonien occidental et biodiv ersité: relations avec la géodynamique andine). The authors are indebted to Badis Kouidrat of Devanlay Peru SAC, for financial and logistic support in the field. Thanks to their compr ehensive knowledge of South American Cenozoic biochronology and endemic ungulates, Alejandro Kramarz and Guillaume Billet greatly improved a previous version of the manuscript.

\section{REFERENCES}

Ameghino F. 1894. - Énumération synoptique des espèces de mammiferes fossiles des formations éocènes de Patagonie. Boletín de la Academia Nacional de Ciencias en Córdoba 13: 259-455.

Antoine P.-O., Baby P., Benammi M., Brusset S., De Franceschi D., Espurt N., Goillot C., Pujos F., Salas-Gismondi R., Tejada J. \& Urbina M. 2007. The Laventan Fitzcarrald local fauna, Amazonian Peru. Cuadernos del Museo Geominero 8: 19-24.

Bond M., Pascual R., Reguero M. A., Santillana S. N. \& MARENSSI S. A. 1990. - Los primeros ungulados extinguidos sudamericanos de la Antártida. Ameghiniana 26: 240.

CABrera Á. 1929. - Un astrapotérido de Colombia. Physis 9: 436-439.

CifelLi R. L. 1993. - The phylogeny of the native South American ungulates, in SZAlay F. S., NovaceK M. J. \& McKenna M. C. (eds), Mammalian Phylogeny. Springer-Verlag, New York: 195-216.

CozzuOL M. A. 2006. - The Acre vertebrate fauna: age, diversity, and geography. Journal of South American Earth Sciences 21: 185-203.

Croft D. A. 2007. — The middle Miocene (Laventan) Quebrada Honda fauna, southern Bolivia and a description of its notoungulates. Palaeontology 50: 277-303.

Espurt N., Baby P., Brusset S., Hermoza W., ANTOINe P.-O., Salas-Gismondi R., Pujos F., Roddaz M., Regard V., Tejada E.R. \& Bolaños R. 2006. Geomorphic and sedimentologic analyses on the fitzcarrald Arch: evidence of a recent tectonic uplift. XIII Congreso Peruano de Geología Extended Abstracts, Sociedad Geológica del Perú: 273-276.

Espurt N., Baby P., Brusset S., Hermoza W., RodDaz M., Antoine P.-O., Regard V. \& Bolaños R. 2007. - Control of the Nazca Ridge subduction on the modern Amazonian foreland basin architecture. Geology 35: 515-518.

Espurt N., Baby P., Brusset S., Roddaz M., Hermoza W. \& Barbarand J. 2010. - The Nazca Ridge and uplift of the Fitzcarrald Arch: implications for regional geology in northern South America, in HoORN C. \& WeSSELINGH F. P. (eds), Amazonia, Landscape and Species Evolution: a Look into the Past. Blackwell-Wiley, Hoboken: 89-100.

Flynn J. J., Novacek M. J., Dodson H. E., Frassinetti D., McKenna M. C., Norell M. A., Sears K. E., Swisher C. C. III \& Wyss A. R. 2002. - A new fossil mammal assemblage from the southern Chilean Andes: implications for geology, geochronology, and tectonics. Journal of South American Earth Sciences 15: 285-302.

Flynn J. J., Charrier R., Croft D. A., Gans P. B., HerRIOTT T. M., WeRTHEIM J. A. \& WySS A. R. 2008. Chronologic implications of new Miocene mammals from the Cura-Mallín and Trapa Trapa formations, Laguna del Laja area, south central Chile. Journal of South American Earth Sciences 26: 412-423.

Forasiepi A. M., Goin F. \& Martinelli A. G. 2009. Contribution to the knowledge of the Sparassocynidae (Mammalia, Metatheria, Didelphoidea), with comments on the age of the Aisol Formation (Neogene), Mendoza Province, Argentina. Journal of Vertebrate Paleontology 29: 1252-1263.

Frailey C. D. 1986. — Late Miocene and Holocene mammals, exclusive of the N otoungulata, of the Rio Acre region, western Amazonia. Contributions in Science, Natural History Museum of Los Angeles County 374: 1-46.

Frailey C. D. 1987. - The Miocene vertebrates of Quebrada Honda, Bolivia. Part I. Astrapotheria. Occasional Papers of the Museum of Natural History, the University of Kansas 122: 1-15.

Gradstein F. M., OGG J. G. \& SMith A. G. 2005. A Geological Time Scale 2004. Cambridge University Press, Cambridge, 589 p.

HofFSTETTER R. 1977. - Un gisement de mammiferes miocènes à Quebrada Honda (Sud Bolivie). Comptesrendus hebdomadaires des séances de l'Académie des Sciences, Paris D: 1517-1520.

HOOKER J. J. 1992. - An additional record of a placental mammal (Order Astrapotheria) from the Eocene of Antarctica. Antarctic Science 4: 107-108.

ISEA A. 1987. - Geological synthesis of the $\mathrm{O}$ rinoco Oil Belt, Eastern Venezuela. Journal of Petroleum Geology 10: 135-148.

JOHNSON S. \& MADDEN R. 1997. — Uruguaytheriine Astrapotheres of Tropical South America, in KAY R., Madden R., Cifelli R. \& FlynN J. J. (eds), Vertebrate Paleontology in the Neotropics. The Miocene Fauna of La Venta, Colombia. Smithsonian Institution Press, Washington and London: 355-382. 
KRAGLIEVICH L. 1928. — Sobre el supuesto Astrapotherium christi, descubierto en Venezuela (Xenastrapotherium n. gen.) y sus relaciones con Astrapotherium magnum $y$ Uruguaytherium beaulieui. Buenos Aires, La Editorial Franco, 16 p.

Kramarz A. 2009. - Adiciones al conocimiento de Astrapothericulus (Mammalia, AstrapotheiaA): anatomia craneo-dentaria, diversidad y distribucion. Revista Brasileira de Paleontologia 12: 55-66.

Kramarz A. G. \& Bond M. 2008. — Revision of Parastrapotherium (Mammalia, Astrapotheria) and other Deseadan astrapotheres of Patagonia. Ameghiniana 45: 537-551.

Kramarz A. G. \& Bond M. 2009. - A new oligocene astrapothere (Mammalia, Meridiungulata) from Patagonia and a new appraisal of astrapothere phylogeny. Journal of Systematic Palaeontology 7: 117-128.

Kramarz A. \& BOND M. 2010. — Colhuehuapian Astrapotheriidae (Mammalia) from Gran Barranca south of Lake Colhue-Huapi, in MADDEN R., CARLINI A., Vucetich M.G. \& Kay R. (eds), The Paleontology of Gran Barranca: Evolution and Environmental Change through the Middle Cenozoic. Cambridge University Press, Cambridge: 182-192.

Lavenu A., Roblet C. \& Winter T. 1995. — Neogene ongoing tectonics in the Southern Ecuadorian Andes: analysis of the evolution of the stress field. Journal of Structural Geology 17: 47-58.

LiNARES O. J. 2004. - Bioestratigrafía de la fauna de mamíferos de las formaciones $S$ ocorro, Urumaco y Codoré (Mioceno medio-Plioceno temprano) de la región de Urumaco, Falcón, Venezuela. Paleobiología Tropical 1: 1-26.

MacFadden B. J., Perez H., Naeser C. W., Zeitler P. K. \& CAMPBell K. E. JR 1990. — Late Cenozoic paleomagnetism and chronology of Andean basins of Bolivia: evidence for possible orclinical bending. Journal of Geology 98: 541-555.

Madden R. H., Guerrero J., Kay R. F., Flynn J. J., Swisher C. C. III \& Walton A. H. 1997. The Laventan Stage and age, in KaY R., Madden R., Cifelli R. \& FlynN J. J. (eds), Vertebrate Paleontology in the Neotropics. The Miocene Fauna of La Venta, Colombia. Smithsonian Institution Press, Washington and London: 499-519.

McKenna M. C. \& Bell S. K. 1997. - Classification of Mammals above the Species Level. Columbia University Press, New York, 631 p.

Negri F. R., Bocquentin Villanueva J., Ferigolo J. \& ANTOINE P.-O. 2010. — 15. A review of Tertiary mammal faunas and birds from western Amazonia, in Hoorn C. \& Wesselingh F. P. (eds), Amazonia, Landscape and Species Evolution: a Look into the Past. Blackwell-Wiley, Hoboken: 245-258.

PasCUAL \& OdReman Rivas 1971. — Evolución de las comunidades de los vertebrados del Terciario argentino.
Los aspectos paleozoogeográficos y paleoclimáticos relacionados. Ameghiniana 8: 372-412.

Paula Couto C. DE 1976. — Fossil mammals from the Cenozoic of Acre, Brazil. I. Astrapotheria. Anais do XXVIII Congresso Brasileiro de Geologia: 237-248.

Paula Couto C. DE 1982. - Fossil mammals from the Cenozoic of Acre, Brasil. V. Notoungulata Nesodontinae (II), Toxodontinae and Haplodontiinae, and Litopterna, Pyrotheria, and Astrapotheria (II). Iheringia 7: 5-44.

Rancy A. 1981. - Mamíferos fósseis do Cenozóico do Alto Juruá-Acre. Unpublished Thesis, Universidade Federal do Rio Grande Do Sul, Porto Alegre, 327 p.

Regard V., Lagnous R., Espurt N., Darrozes J., Baby P., Roddaz M., Calderón Y. \& Hermoza W. 2009. - Geomorphic evidence for recent uplift of the Fitzcarrald Arch (Peru): a response to the Nazca Ridge subduction. Geomorphology 107: 107-117.

Salas-Gismondi R., Antoine P.-O., Baby P., BENAMmi M., Espurt N., Pujos F., TejadA J., Urbina M. \& De FRANCESCHI D. 2007. — Middle Miocene crocodiles from the Peruvian Amazonian basin (Fitzcarrald Arch). Cuadernos del Museo Geominero 8: 355-360.

SánChez-Villagra M. R., Asher R. J., Rincón A. D., Carlini A. A., MeYlan P. \& Purdy A. W. 2004. New faunal reports for the Cerro La Cruz locality (lower Miocene), north-western Venezuela, in Sánchez-Villagra M. R. \& Clack J. A. (eds), Fossils of the Miocene Castillo Formation, Venezuela: contributions on neotropical palaeontology. Special Papers in Palaeontology 71: 105-112.

ScotT W. B. 1928. - Astrapotheria, in SсOTT W. B. (ed.), Reports of the Princeton University Expeditions to Patagonia, 1896-1899. Volume VI. Paleontology. Mammalia of the Santa Cruz beds. Part IV. E. Schweizerbart'sche Verlagshandlung (E. Nägele), Stuttgart: 301-351.

ScOTT W. B. 1937. - The Astrapotheria. Proceedings of the American Philosophical Society 77: 309-393.

SiMPSON G. G. 1940. — Review of the mammal-bearing Tertiary of South America. Proceedings of the American Philosophical Society 83: 649-710.

SiMPSON G. G. 1945. - The principles of classification and a classification of mammals. Bulletin of the American Museum of Natural History 85: 1-350.

SIMPSON G. G. 1967. - The beginning of the age of mammals in South America. Part 2. Bulletin of the American Museum of Natural History 137: 1-259.

STEHLIN H. G. 1928. - Ein Astrapotheriumfund aus Venezuela. Eclogae Geologicae Helvetiae 21: 227-232.

STIRTON R. A. 1953. - A new genus of interatheres from the Miocene of Colombia. University of California Publications in Geological Sciences 29: 265-348.

WaLton A. H. 1997. — Rodents, in KaY R. F., MADDEN R. H., CifElli R. L. \& FlynN J. J. (eds), Vertebrate Paleontology in the Neotropics. The Miocene Fauna of 
La Venta, Colombia. Smithsonian Institution Press, Washington: 392-409.

Weston E. M., MAdDEn R. H. \& SÁNChez-Villagra M. R. 2004. - Early Miocene astrapotheres (Mammalia) from northern South America, in SÁNCHEZVillagra M. R \& Clack J. A. (eds), Fossils of the
Miocene Castillo Formation, Venezuela: contributions on neotropical palaeontology. Special Papers in Palaeontology 71: 81-97.

Willard B. 1966. - The Harvey Bassler Collection of Peruvian Fossils. Lehigh University, Bethlehem, PA, $104 \mathrm{p}$.

Submitted on 10 February 2010; accepted on 18 June 2010. 